\title{
Erratum to: Further evidence for addition and numerical competence by a Grey parrot (Psittacus erithacus)
}

Irene M. Pepperberg

Published online: 9 March 2012

(C) Springer-Verlag 2012

\section{Erratum to: Anim Cogn}

DOI 10.1007/s10071-012-0470-5

In the original version of article, there is an error in the acknowledgments section. The correct sentence is given below:

This manuscript was written under the support of donors to The Alex Foundation (particularly Anita Keefe, Michael Shuman and the Marc Haas Foundation, and the Sterner family) and NSF grant BCS0920878 (to Ken Nakayama).

The online version of the original article can be found under doi:10.1007/s10071-012-0470-5.

I. M. Pepperberg $(\bowtie)$

Department of Psychology, Harvard University,

Cambridge, MA, USA

e-mail: impepper@media.mit.edu 